\title{
Source Apportionment of Particle Bound Polycyclic Aromatic Hydrocarbons at an Industrial Location in Agra, India
}

\begin{abstract}
Anita Lakhani
Department of Chemistry, Dayalbagh Educational Institute, Agra 282005, India

Correspondence should be addressed to Anita Lakhani, anitasaran2003@yahoo.co.in

Received 25 October 2011; Accepted 11 December 2011

Academic Editor: Xavier M. Querol

Copyright () 2012 Anita Lakhani. This is an open access article distributed under the Creative Commons Attribution License, which permits unrestricted use, distribution, and reproduction in any medium, provided the original work is properly cited.

16 USEPA priority polycyclic aromatic hydrocarbons (PAHs) were quantified in total suspended ambient particulate matter (TSPM) collected from an industrial site in Agra (India) using gas chromatography. The major industrial activities in Agra are foundries that previously used coal and coke as fuel in cupola furnaces. These foundries have now switched over to natural gas. In addition, use of compressed natural gas has also been promoted and encouraged in automobiles. This study attempts to apportion sources of PAH in the ambient air and the results reflect the advantages associated with the change of fuel. The predominant PAHs in TSPM include high molecular weight (HMW) congeners BghiP, DbA, IP, and BaP. The sum of 16 priority PAHs had a mean value of $72.7 \pm 4.7 \mathrm{ng} \mathrm{m}^{-3}$. Potential sources of PAHs in aerosols were identified using diagnostic ratios and principal component analysis. The results reflect a blend of emissions from diesel and natural gas as the major sources of PAH in the city along with contribution from emission of coal, coke, and gasoline.
\end{abstract}

\section{Introduction}

Polycyclic aromatic hydrocarbons (PAHs) are comprised of carbon and hydrogen atoms in two or more aromatic rings [1]. They are a group of ubiquitous persistent organic pollutants possessing carcinogenic, mutagenic, and immunotoxic properties [2]. They occur in the atmosphere due to emissions from gasoline- and diesel-powered vehicles and other sources such as coal, biomass, gas, and oil combustion [3-7]. The strainless arrangement of $s p^{2}$-hybridized carbon atoms in six membered rings and, above all, the energy gain from the delocalized p-electrons, makes PAHs thermally very stable and therefore $\mathrm{PAH}$ are abundant molecules in the combustion zone. Therefore, they are always formed in combustion processes and are attributed to unburned, pyrolyzed, or partially oxidized fuel and lubricant oil that are transferred from the gas phase to the particulate phase by adsorption and condensation onto the existing particles or by nucleation of new particles when the exhaust cools [2].

PAHs occur in gaseous form and are adsorbed to particles in the atmosphere, depending on the volatility of the $\mathrm{PAH}$ species. Higher condensed molecules with four and more rings are particle-bound, whereas smaller PAHs mainly remain in the gas phase [8]. Once PAHs are released into the atmosphere, they are subjected to various atmospheric processes through which their dispersion, removal, transport and degradation can occur. Dispersion of atmospheric PAH is dependent not only on the magnitude of the emissions but also on the stability of PAH in the atmosphere [8]. PAH concentration is highly dependent upon the size of airborne particulate matter, with the greatest concentration being in the respirable size range [9].

PAHs have attracted much attention in the studies on air pollution recently because some of them are highly carcinogenic or mutagenic. In particular, benzo(a)pyrene has been identified as a highly carcinogenic [10]. The occurrence of PAH in urban air has caused particular concern because of the continuous nature of the exposure and the size of the population at risk. Humans can be affected by direct inhalation of polluted air, tobacco smoke, ingestion of contaminated and processed food and water, and through dermal contact.

PAHs have been less monitored in Asia, specifically in India, in comparison to its western counterpart. India is 
a developing nation which has experienced an increase in population and industrial expansion that has been accompanied by drastic increase in vehicular transportation. Information on the airborne concentration of toxic pollutants in developed countries is relatively abundant. However, for less developed nations as India, data are not routinely collected. In India, studies on measurements of PAHs in the ambient air of major cities are limited. Total PAH concentrations in ambient aerosols in Ahmedabad, Mumbai, Nagpur, Calcutta, and Kanpur show that PAH concentrations are 10-50 times higher than those reported internationally and range between 23 and $190 \mathrm{ng} \mathrm{m}^{-3}$ [11-15]. In an earlier study, it was reported that the annual average total $\mathrm{PAH}$ concentrations at four locations in New Delhi, which ranged from 150 to $1,800 \mathrm{ng} \mathrm{m}^{-3}$, were dominated by vehicular traffic [16]. Recently atmospheric concentrations of total PAHs were found to range from 1,049 to $1,344 \mathrm{ng} \mathrm{m}^{-3}$ at three sites in Delhi with higher concentrations in winter. Diesel- and gasolinedriven vehicles were identified as the principal sources of PAHs [17]. In addition, in the Indian urban environment, cooking fuel combustion is also a likely source of PAH. High concentrations of PAH have been measured in smoke from solid-fuel stoves burning wood, coal, and dried cattle manure [11], which along with kerosene stoves [18] are used as the primary cooking device by urban slum residents.

Agra, located in the state of Uttar Pradesh of northern India, is known for Taj Mahal, one of the wonders of the world. In addition to Taj Mahal, there are three more world heritage sites, namely, Agra Fort, Fatehpur Sikri, and the bird sanctuary at Bharatpur National Park. In addition, the Akbar's tomb at Sikandra in Agra (in proximity to Agra) and the Imtad-ud-Daulahs tomb in Agra are proposed as world heritage sites. The majority of industries in Agra comprise of foundries and several diesel generator manufacturing units. In foundries, the principal source of emission is cupola. The volume of gas exhausted and its concentration depends on the cupola, operations, melting rates, characteristic of charging material, and the coke [19]. Gases escape while drawing the hot metal and during casting. In the pit type of cupola, emissions are fugitive type. Besides a number of petha ( $a$ sweet) industries are operating in the city, which mainly use coal as fuel. There are also several sweet shops, pottery units that use coal, cow dung, and wood [19]. The vehicle fleet in Agra comprises of trucks, buses, delivery vans, taxis, private cars, and autorickshaws that are mainly diesel driven. The number of registered on-road diesel vehicles in Agra till January 2008 was approximately 51,938 [20]. Diesel-driven generators are almost exclusively used in the industrial units as well as in the households as a stand by to meet power requirements during periods of load shedding. The diesel quality used earlier was poor containing a high $\mathrm{S}$ content, to the extent of $0.25 \%$, and a large amount of aromatics [19]. Moreover, a large population of the slum residents of the area use coal, coke, wood, kerosene, and cow dung cakes as the domestic fuel, which is burnt in small home made cook stoves.

The area in the immediate vicinity of the Taj Mahal in the form of a trapezoid is known as the Taj Trapezium Zone. It extends between $27^{\circ} 30^{\prime} \mathrm{N}$ and $77^{\circ} 30^{\prime} \mathrm{E}$ to $27^{\circ} 45^{\prime} \mathrm{N}$ and $77^{\circ} 15^{\prime} \mathrm{E}$ and $26^{\circ} 45^{\prime} \mathrm{N}$ and $77^{\circ} 15^{\prime} \mathrm{E}$ to $27^{\circ} 00^{\prime} \mathrm{N}$ and $78^{\circ} 30^{\prime}$ E. In 1999, the Ministry of Environment and Forest, Government of India, has notified the Taj Trapezium Zone (Pollution Prevention and Control) Authority for protection and improvement of the environment in the Trapezium. In this connection several actions have been taken to control industrial and vehicular pollution. Industries have been encouraged to use natural gas instead of coal and there is strict vigilance on these industries not to use coal or coke; the brick kilns that were previously operational around the city have been closed. Likewise stringent actions have also been taken to control vehicular pollution. These include phasing out of grossly polluting vehicles plying within the city area and age limits for different categories of vehicles were fixed by Road Transport Authority (RTA). Diesel-driven autos fitted with particle traps are only given license and registration and to control emissions low sulfur $(0.05 \%)$ diesel is made available. More and more CNG/LPG (compressed natural gas/liquefied natural gas) and battery-operated vehicles are being promoted. Similarly gas-driven electricity generator sets have been developed and their use has been encouraged. Simultaneously for the in-use vehicles strict checking of vehicular emissions is performed [19].

In the recent past we have conducted PAH measurement in total suspended particulate matter at Agra for short durations at different locations $[7,21]$. These studies also revealed higher concentrations of PAH in TSPM that were mainly attributed to originate from vehicular traffic and combustion of coal and biomass comprising wood, crop residues, and agricultural wastes burnt in the domestic and industrial sector. In the present study results of $\mathrm{PAH}$ measurements carried out from May 2006 to December 2008 at a location close to the industrial area as well as the major highway (NH-2) crossing in the city are presented. An attempt has also been made to see the influence of the use of cleaner fuels through determination of sources of PAH by principal component analysis.

\section{Materials and Methods}

2.1. Description of Sampling Site. Agra is situated in the extreme southwest corner of Uttar Pradesh and stretches across $26^{\circ} 44^{\prime} \mathrm{N}$ to $27^{\circ} 25^{\prime} \mathrm{N}$ and $77^{\circ} 26^{\prime} \mathrm{E}$ to $78^{\circ} 32^{\prime} \mathrm{E}$. Its borders touch Rajasthan to its west and south, the district of Firozabad to its East, and the districts of Mathura and Etah to its North. It is situated on the banks of river Yamuna, and it has a limited forest area supporting mainly deciduous trees. According to census 2001, the area of Agra district is $4027 \mathrm{~km}^{2}$ with a total population of about $1,316,177$ and density about 21,148 of $\mathrm{km}^{2}$ with 386,635 vehicles registered and 32,030 generator sets. In Agra, 60\% of NOx pollution is due to vehicles [20]. Three national highways (NH-2, NH11, and NH-3) pass through the city. Like most cities of north India, the weather and climate of Agra is extreme and tropical. Agra suffers from extremities of climate with scorching hot summers and chilly winters. It is about $169 \mathrm{~m}$ above the mean sea level (msl) and has been reported [19] as having semiarid climate with atmospheric temperature in the range of $11-48^{\circ} \mathrm{C}(\max ) 0.7-30^{\circ} \mathrm{C}(\mathrm{min})$, relative humidity 
25-95\%, light intensity $0.7-5.6$ oktas (cloudiness), and rainfall $650 \mathrm{~mm}$ per year. The climate of Agra has been broadly divided into three seasons: winter (October to February), summer (March to June), and monsoon (July to September). During monsoon period the temperature ranges between 26 and $39^{\circ} \mathrm{C}$ and relative humidity varies between 70 and $100 \%$, respectively [19]. The winter months are cool and temperature ranges from 2 to $15^{\circ} \mathrm{C}$ while relative humidity is 60 to $90 \%$. Summers are characterized by high temperature ranging from 23 to $45^{\circ} \mathrm{C}$ and low relative humidity 25 to $40 \%$.

Sampling was conducted on the roof of a single storeyed building situated in proximity to the industrial area as well as about $1.5 \mathrm{~km}$ from a busy roadway intersection situated on the National Highway Number2 (NH-2). NH-2 connects Delhi to Kolkata via Agra and is one of the busiest highways. On an average six to seven thousand vehicles ply on this highway and comprise about 3500 light motor vehicles (LMV), 500 light commercial vehicles (LCVs), and 2500 heavy commercial vehicles (HCVs) [22]. In this study total suspended particles (TSPs) were collected during May 2006 to December 2009 using a high-volume sampler. The samples were collected on predesiccated and preweighed glass fibre filters (Whatman, EPM 2000). Air was drawn at a flow rate of $1.1 \mathrm{~m}^{3} \mathrm{~min}^{-1}$ for $24 \mathrm{hr}$ on an average. The accurate flow rate of the sampling device was determined by averaging the flow rates measured at the beginning and the end of the sampling period. Before bringing the samples to the laboratory, the filters were packed in aluminium foils to protect them from dust and were stored at low temperature to prevent the volatilization of low molecular weight PAHs.

The particulate matter contained in the filter was extracted thrice by using ultrasonic agitation with $200 \mathrm{~mL}$ dichloromethane for $1 \mathrm{hr}$ after intervals of $10 \mathrm{~min}$ after every $15 \mathrm{~min}$ to ensure maximum recovery. All the three extracts were mixed together to make a composite sample. The extract was purified by means of cleanup in silica gel column to remove elements interfering in the analysis. The extract was transferred to the top of a glass column $(10 \mathrm{~cm} \times 1.0 \mathrm{~cm}$ i.d.) slurry packed with $2 \mathrm{~g}$ of silica gel (Fluka, 230 mesh). The column was eluted with dichloromethane to give fraction enriched with $\mathrm{PAH}$. The PAH containing fraction was concentrated to $1.5 \mathrm{~mL}$ by a rotary evaporator and stored in Teflon vials at low temperature till analysis.

PAHs were analyzed in the splitless mode using a temperature gradient program [23] by gas chromatograph, (Shimadzu 17AATF, version 3.0) equipped with a FID detector and capillary column ( $25 \mathrm{~m}$ length, $0.3 \mathrm{~mm}$ internal diameter: BP) with dimethyl polysiloxane as stationary phase. Nitrogen was the carrier gas at a flow rate of $12.7 \mathrm{~mL} \mathrm{~min}^{-1}$. The oven temperature was held at $40^{\circ} \mathrm{C}$ for 5 minutes and programmed to rise to $179^{\circ} \mathrm{C}$ at $10^{\circ} \mathrm{C} \mathrm{min}-1$, held for 2 minutes, and then elevated to $300^{\circ} \mathrm{C}$ at $9^{\circ} \mathrm{C} \mathrm{min}^{-1}$. The temperature of injector and detector was maintained at $210^{\circ} \mathrm{C}$ and $310^{\circ} \mathrm{C}$, respectively. The GC was calibrated with a standard solution of 16 PAH compounds (Supelco EPA 610 $\mathrm{PAH}$ mixture). The procured PAH mixture contained the following 16 EPA priority PAHs in mixed solvent (methanol: dichloromethane; vol/vol, 1:1); Naphthalene (Nap), Acen- aphthylene (Acy), Acenaphthene (Ace), Fluorene (Flu), Phenanthrene (Phen), Anthracene (Anth), Fluoranthene (Fla), Pyrene (Pyr), Benzo(a)anthracene (BaA), Chrysene (Chr), Benzo(b)fluroanthene (BbF), Benzo(k)fluoranthene $(\mathrm{BkF})$, Benzo(a) pyrene $(\mathrm{BaP})$, Dibenzo $(\mathrm{a}, \mathrm{h})$ anthracene $(\mathrm{DbA})$, Benzo(ghi)perylene (BghiP), and Indeno (1,2,3-cd)pyrene (IP) in the range of 100 to $2000 \mu \mathrm{g} \mathrm{mL}^{-1}$. Five point calibration curves for all the target analytes ranging were obtained by analysis of serial dilution of PAHs standard. Calibration curves were plotted by regression analysis. $1 \mu \mathrm{L}$ of the extracted sample was injected into GC and the program was set to run for 40 minutes. Individual PAH were identified by comparing their retention time with the standard chromatogram. Each PAH compound was quantified by plotting its peak area on the regression curve of standard. The limit of detection of the chromatographic method determined through serial dilution of the PAH standard varied between 0.007 and $0.16 \mathrm{ng}$ for the different compounds. The limit of quantification (LOQ) defined as the limit of detection divided by the sampling volume [24] was in the range of $1.8 \times 10^{-7}$ and $4.10 \times 10^{-5} \mathrm{ng} \mathrm{m}^{-3}$ [7]. The recovery efficiency of the method was evaluated by the analysis of filters spiked with known concentration of standard PAH compounds [7]. Most of the compounds provided high recoveries with mean values ranging between 70 and $80 \%$. Field and laboratory blank were routinely analyzed for quality control. Blanks levels of individual analytes were normally very low and in most cases not detectable. Some PAH compounds like $\mathrm{BaA}$ and $\mathrm{Chr}, \mathrm{BbF}$ and $\mathrm{BkF}$, and $\mathrm{DbA}$ and IP coelute in the method followed in this study; hence these coeluting pairs have been reported as their sum [25].

\section{Results and Discussion}

3.1. PAH Concentrations and Seasonal Variations. Both TSP and PAH concentration presented a large variability with a skewed distribution. The geometric mean concentrations of TSP, individual PAH, and total PAH (i.e., sum of all determined PAH in each sample, TPAH) are listed in Table 1.

The mean concentration of individual PAH ranged from 0.9 to $20.5 \mathrm{ng} \mathrm{m}^{-3}$. PAH can be classified into low molecular weight compounds (Nap, Acy, Ace Flu, Phen, Anth, Fla and Pyr) and high molecular weight compounds $(\mathrm{BaA}, \mathrm{Chr}$, $\mathrm{BbF}, \mathrm{BkF}, \mathrm{BaP}, \mathrm{DbA}$, IP, and BghiP). The characteristic mass distribution pattern of PAH shows that the mass distribution in air was dominated by high molecular weight $\mathrm{PAH}$ with 5 to 6 rings such as BbF, BkF, DbA, IP, BaA, Chr, BaP and BghiP. PAHs are semivolatile organic compounds and occur in both gaseous and particulate phases in the atmosphere. The vapor-particle partition exhibits a strong dependence on molecular weight. High molecular weight compounds dominate in the particulate phase while low molecular weight PAHs reach higher concentrations in the vapor phase. The HMW PAHs are mainly derived from the vehicular emissions and are known to exist adsorbed on particulate matter owing to their low vapor pressure. Moreover, some of the higher molecular weight PAHs in the air are short lived; half life is about $2.4 \mathrm{~h}$ for $\mathrm{BaP}, 1-13 \mathrm{~h}$ for $\mathrm{DbA}$ and $\mathrm{BaA}$, and $0.31-10 \mathrm{~h}$ for BghiPs, therefore, they are easily detected at 
TABLE 1: Mean and standard deviations for all PAHs $\left(\mathrm{ng} \mathrm{m}^{-3}\right)$.

\begin{tabular}{|c|c|c|}
\hline & Average & Standard deviation $\left(\mathrm{ng} \mathrm{m}^{-3}\right)$ \\
\hline Naphthalene (NaP) & 0.9 & 1.7 \\
\hline Acenaphthylene (Acy) & 1.7 & 4.7 \\
\hline Acenaphthene (Ace) & 1.8 & 1.2 \\
\hline Fluorene (Flu) & 1.0 & 0.7 \\
\hline Phenanthrene (Phen) & 0.9 & 0.2 \\
\hline Anthracene (Anth) & 2.2 & 1.3 \\
\hline Fluoranthene (Fla) & 0.9 & 1.3 \\
\hline Pyrene (Pyr) & 3.1 & 2.3 \\
\hline Benzo(a)anthracene + Chrysene $(\mathrm{BaA}+\mathrm{Chr})$ & 14.1 & 4.7 \\
\hline Benzo(b)fluoranthene + Benzo(k)fluoranthene $(\mathrm{BbF}+\mathrm{BkF})$ & 20.5 & 6.8 \\
\hline Benzo(a)pyrene (BaP) & 12.3 & 6.0 \\
\hline $\operatorname{Dibenz}(\mathrm{ah})$ anthracene + Indeno $(123-\mathrm{cd})$ pyrene $(\mathrm{DbA}+\mathrm{IP})$ & 17.3 & 3.1 \\
\hline B(ghi)perylene (BghiP) & 11.1 & 6.2 \\
\hline TPAH & 72.7 & 4.7 \\
\hline TSPM* & 348 & 31.5 \\
\hline $\mathrm{CPAH}$ & 47.6 & - \\
\hline СРAH/ТРAH & 0.66 & - \\
\hline Total Carcinogenic PAH & $64 \%$ & - \\
\hline
\end{tabular}

$* \mu \mathrm{g} \mathrm{m}{ }^{-3}$.

sites where sampling is carried out close to emission sources [26]. Among the low molecular weight compounds Acy, Ace, and Anth are in higher concentrations than Pyr, Fla, Flu, and Phen. The sum of the concentration of nine major combustion PAHs (CPAH) (Fla, Pyr, BaA, Chr, $B(b+k) F$, $\mathrm{BaP}$, IP, and BghiP) accounted for $77 \%$ of the total PAH mass. The ratio of CPAH/TPAH was 0.66 and is higher than the ratio reported for noncatalyst $(0.41)$, catalyst $(0.51)$ automobiles, and heavy duty diesel trucks (0.30) [27]. Noncatalyst vehicles emit 27 times more PAHs especially HMW PAHs than catalyst-equipped vehicles [27]. Less efficient emission control system in the vehicle fleet and more extensive combustion activities in the city may account for this high CPAH/TPAH ratio. Sum of the carcinogenic PAHs including $\mathrm{BaA}, \mathrm{BbF}, \mathrm{BkF}, \mathrm{BaP}, \mathrm{DbA}$, and IP accounted for $64 \%$ of TPAH. IARC has classified total carcinogenic PAH as "probably carcinogenic" to humans (namely, BaA, BaP, and $\mathrm{DbA}$ ) and as "possibly carcinogenic" to humans (namely, $\mathrm{BbF}, \mathrm{BkF}$, and IP) [28]. In the present study the "probably car-cinogenic" compounds accounted for $38 \%$ while "possibly carcinogenic" compounds accounted for $26 \%$ of total PAH. The carcinogenic PAH have high molecular weights and are especially bound to suspended particles. $\mathrm{BaP}$ has been the most extensively measured $\mathrm{PAH}$ in urban areas around the world due to its high carcinogenic property. Average BaP concentration at the site was $12.3 \mathrm{ng} \mathrm{m}^{-3}$, that is, less than the permissible exposure limit $\left(0.2 \mathrm{mg} \mathrm{m}^{-3}\right)$ of PAH set by the Occupational Safety and Health Administration (OSHA) [29].

Atmospheric PAH levels can differ to an extent of $40 \%$ depending on the sampling system, extraction solvents, analytical techniques, and detectors [30]. PAHs determined in airborne particles are also influenced by regional climatic and source characteristics [31]. A comparison has been made with other Indian sites in Table 2.

$\mathrm{PAH}$ concentrations varied inversely with temperature ( $r=-0.65, P=0.05)$, that is, higher concentrations in the cold months and lower ones in the warm months. The winter-to-summer ratio of individual compounds varied between 1.14 (DbA) and 2.65 (IP). The increase in particulate PAH concentration during the winter and the dependence of PAH concentration on atmospheric temperature have been reported in a number of studies [35-38]. Source emissions and meteorological conditions as well as gas particle partitioning may result in winter and summer difference of PAHs concentrations [39]. Reduced atmospheric dispersion resulting from lower mixing height as well as reduced atmospheric reaction can lead to higher pollutant concentrations in ambient air during winter. Low atmospheric temperature can affect the distribution of PAHs between the gas and particle phases and result in a relatively larger portion of PAH partitioning to the particle phase in winter. In contrast during the summer a higher ambient temperature could change the distribution of PAHs between the gaseous and particulate phases by increasing the vapor pressure of pollutants that adhered to atmospheric aerosols and favoring the volatilization of PAHs from the particulate to gaseous phase. It is also well known that PAHs in the atmosphere are subjected to photochemical or thermal reactions with ozone, nitric oxides, and hydroxyl radicals that lead to PAHs degradation, especially in the warmer seasons [40]. High solar radiation could enhance the reaction of volatile organic compounds in forming ozone active hydroxyl radicals that in turn react with PAHs and reduce their concentrations [41]. In addition to temperature effects on the physicochemical property of atmospheric PAHs, anthropogenic factors can also lead to 
TABLe 2: Comparison of total PAHs $\left(\mathrm{ng} \mathrm{m}^{-3}\right)$ with various cities of India.

\begin{tabular}{|c|c|c|c|c|c|c|}
\hline Total PAHs & Range & City & Substrate & Extraction & Analysis & Reference \\
\hline $\begin{array}{l}\sum 11 \mathrm{PAHs} \\
\left(\mathrm{PM}_{2.5}\right)\end{array}$ & $\begin{array}{c}326-791 \\
\text { (Mean at } 4 \text { Sites) }\end{array}$ & Chennai & $\begin{array}{l}\text { PTFE membrane } \\
\text { Filters }\end{array}$ & $\begin{array}{c}\text { DCM : Methanol } \\
\quad(60: 40) ; \\
\text { Ultrasonication }\end{array}$ & $\begin{array}{c}\text { HPLC } \\
\text { (Fluorescence Detector) }\end{array}$ & {$[32]$} \\
\hline $\begin{array}{l}\sum 9 \text { PAHs } \\
\left(\mathrm{PM}_{2.5}\right)\end{array}$ & $\begin{array}{c}202.6-333.7 \\
\text { (Mean at } 4 \text { Sites) }\end{array}$ & Tiruchirappalli & $\begin{array}{l}\text { PTFE membrane } \\
\text { Filters }\end{array}$ & $\begin{array}{c}\text { DCM : Methanol } \\
\quad(60: 40) ; \\
\text { Ultrasonication }\end{array}$ & $\begin{array}{c}\text { HPLC } \\
\text { (Fluorescence Detector) }\end{array}$ & {$[32]$} \\
\hline $\begin{array}{l}\sum 11 \mathrm{PAHs} \\
\left(\mathrm{PM}_{10}\right)\end{array}$ & $\begin{array}{c}\text { 8-97.9 } \\
\text { (Mean at } 4 \text { Sites) }\end{array}$ & Agra & Glass fibre filter & $\begin{array}{l}\text { Methylene Chloride; } \\
\text { Soxhlet Extraction }\end{array}$ & GC-MS & {$[33]$} \\
\hline $\begin{array}{l}\sum 12 \mathrm{PAHs} \\
(\mathrm{TSP})\end{array}$ & $\begin{array}{c}\text { 1049-1344 } \\
\text { (Mean at } 3 \text { Sites) }\end{array}$ & Delhi & Glass fibre filter & $\begin{array}{c}\text { Toluene; } \\
\text { Ultrasonication }\end{array}$ & GC-FID & {$[17]$} \\
\hline $\begin{array}{l}\sum 12 \mathrm{PAHs} \\
(\mathrm{TSP})\end{array}$ & $672($ Mean $)$ & Delhi & Glass fibre filter & $\begin{array}{c}\text { Toluene; } \\
\text { Ultrasonication }\end{array}$ & GC-FID & {$[34]$} \\
\hline $\begin{array}{l}\sum 16 \text { PAHs } \\
\text { (TSP) }\end{array}$ & 72.7 (Mean) & Agra & Glass fibre filter & DCM Ultrasonication & GC-FID & Present Study \\
\hline
\end{tabular}

TABLE 3: Diagnostic ratios.

\begin{tabular}{|c|c|c|c|c|c|c|c|}
\hline & Present study & Diesel & Gasoline & Wood & Coal & Other sources & References \\
\hline \multirow{5}{*}{ IP/(IP + BghiP $)$} & 0.72 & 0.37 & & 0.62 & 0.56 & & {$[54]$} \\
\hline & & $0.35-0.7$ & 0.18 & & & & {$[53,54]$} \\
\hline & & & $0.21-0.22$ & & & & [27] \\
\hline & & & & & 0.33 & & [49] \\
\hline & & & & & & & {$[53]$} \\
\hline \multirow{3}{*}{$\mathrm{BaA} /(\mathrm{BaA}+$ Chy $)$} & 0.44 & $0.38-0.64$ & & & & & {$[52]$} \\
\hline & & & $0.22-0.55$ & & & & {$[52]$} \\
\hline & & & & & 0.50 & & {$[53]$} \\
\hline $\mathrm{BaP} /(\mathrm{BaP}+\mathrm{Chy})$ & 0.61 & $>0.73$ & 0.49 & & & & {$[46,55]$} \\
\hline Phen/(Phen + Anth $)$ & 0.68 & 0.65 & 0.5 & & 0.76 & $>0.70$ (Crude oil) & {$[51,55]$} \\
\hline $\mathrm{BaA} / \mathrm{BaP}$ & 0.50 & $0.90-1.70$ & $0.50-0.70$ & $1.0-1.5$ & & & {$[50]$} \\
\hline $\mathrm{BbF} / \mathrm{BkF}$ & 1.08 & $>0.5$ & & & & & {$[52]$} \\
\hline
\end{tabular}

seasonal variation of particulate PAHs. During the cold season, PAH emissions from automobile exhaust are higher because of low ambient temperature and increased cold start impacts [42]. Another reason for the higher concentrations in winter could be due to an increase in the emissions owing to the fossil fuel usage for space heating purposes. Sharma et al. [17] have also found winter/summer ratios of total PAH between 2.41 and 3.69 at three sites in Delhi. However PAHs in winter have been found higher by a factor of 1.5-10 than that in summer in studies carried out in Europe and the USA [8, 43-45]. Similarly, Guo et al. [46] found high winter/ summer ratios of 8.6 and 7.5 at two sites in the city of Hong Kong.

The contribution of the combustion-derived $\mathrm{PAH}$ $(\mathrm{CPAH})$ to total PAH also varied between the two seasons. Their contributions were 64 and $72 \%$, respectively, in summer and winter. The lower contribution is summer meant that vehicular emissions may be a contribution in summer while in the winter season, emission sources were more complex.

3.2. Diagnostic Analysis and Principal Component Analysis. Studies indicate that particulate organic samples collected in tunnels are enriched in benzo(ghi)perylene and coronene, which are characteristic of gasoline engines [47]. Diesel exhaust is found to be enriched in Fla, Chr, and Pyr [48] while Anth, Phen, Fla, and Pyr have been identified as source fingerprints of wood combustion and $\mathrm{BaA}$ and $\mathrm{Chr}$ as markers of coal combustion [49]. The concentrations of these marker compounds and their ratios can give some indication about the impact of different sources of airborne compounds and can be used in distinguishing emissions $[49,50]$. In this study, the following PAH concentration diagnostic ratios characteristic of the anthropogenic emissions were calculated: IP (IP + BghiP), BaA/(BaA + Chr $), \mathrm{BaP} /(\mathrm{BaP}+$ Chr), BghiP/IP, Phen/(Phen + Anth), BaA/BaP, and BbF/BkF. A comparison between the various diagnostic ratios obtained in this study with the standard values reported in the literature is shown in Table 3. Analysis of the ratios could be associated to various sources. The IP/(IP + BghiP $)$ ratio is found to be 0.72 , which is similar to that reported for diesel and gasoline emissions $[27,44,46]$. Similarily the value of $\mathrm{BaA} /(\mathrm{BaA}+\mathrm{Chr})$ ratio has been reported to vary between 0.38 and 0.64 for diesel emissions and between 0.22 and 0.5 for gasoline emissions [51, 52]. For emissions from coal burning this ratio has been observed to be 0.50 [53]. 
In the present study this ratio is 0.44 which can be attributed to vehicular (diesel and gasoline) emissions. The vehicular influence can further be assessed from Phen/(Phen + Anth) ratio whose value of 0.68 is comparable to values reported for diesel, coal, and crude oil burning and gasoline emissions $[49,51]$. The ratio $\mathrm{BaP} /(\mathrm{BaP}+\mathrm{Chr})$ with its value 0.61 again indicates towards contributions from diesel emissions. The $\mathrm{BaA} / \mathrm{BaP}$ and BghiP/IP ratios of 0.50 at this site may be inferred to the contribution from gasoline emissions [50]. Further $\mathrm{BbF} / \mathrm{BkF}$ ratio with a value $>0.5$ may be attributed to diesel emissions [10]. These results suggest the influence of multiple sources like the burning of fuels, such as diesel oil, gasoline, and coal. Thus diagnosis of ratios contributes quantitatively to the identification of the main emission sources in the studied area. It is to be noted that the diagnostic ratios method should be used with caution because it is often difficult to discriminate between some sources [4]. For example, a ratio of 0.62 for IP/IP + BghiP has been suggested for wood burning [54] whereas a value between 0.35 and 0.70 indicates diesel emissions [55]. Hence, it would be difficult to differentiate diesel emission from biomass emission based only on one proposed diagnostic ratio. Recently Galarneau [56] has reviewed the caveats associated with the use of diagnostic ratios in source apportionment of PAHs in ambient air. The validity of this approach rests on the assumption that each source or source type is associated with relative proportions of the compounds that are unique and secondly the relative proportions of the compounds are assumed to be conserved between the emission source and the receptor or the points of measurement. These assumptions hold for $\mathrm{PAH}$ under limited set of conditions [56]. These ratios can also be altered due to the reactivity of some PAH species with other atmospheric species like ozone and/or oxides of nitrogen or by the volatility and solubility of some PAH $[4,57]$. To minimize this bias, the diagnostic ratio of $\mathrm{PAH}$ with similar physicochemical properties should be used. Degradation processes during the sampling process may also modify $\mathrm{PAH}$ concentrations and thus the ratios between PAHs.

In addition to the diagnostic ratios between $\mathrm{PAH}$, Principal Component Analysis (PCA) was used as an exploratory tool as it enhances the accuracy of emission source identification by selecting statistically independent source tracers [46]. This method segregates measured ambient concentrations according to groups of covarying compounds and comparing these groups to suspected source profiles. Thus using PCA, it is possible to simplify the interpretation of complex systems and to reduce the set of variables to few new ones, called factors. Each of these factors can be identified as either an emission source or a chemical interaction by the most representative compounds. Some PAH compounds and their combinations are frequently used as source markers such as Flu, Chr, and Pyr for diesel exhaust [46, 58], Flu, Pyr, $\mathrm{BbF}$, and BkF for heavy duty diesel vehicles [4, 59], BghiP for gasoline vehicles $[4,58,60]$, Flu and $\mathrm{BaP}$ [31] or Ant, Phe, Flu, and Pyr [4, 5, 31, 49] or $\mathrm{NaP}$ and Ant [49] for wood combustion, Ant, Phe, Flu, Pyr, BaA, and Chr for coal combustion $[4,5,49,60]$, Phe and Flu [4, 49] for coke production, Flu and Pyr $[4,61]$ for oil burning, and Ant, Phe, BaP, BghiP, and Chr [4] for steel industry emissions.
Before subjecting the data to PCA, a pretreatment involving an autoscaling of the data was performed. In this autoscaling procedure all variables were mean centered and scaled to unit variance, by subtracting the mean $x_{j}$ of each variable $j$ from the result $x_{i j}$ of each sample $i$ for that variable and dividing the result by the standard deviation $s_{j}$ of that variable. The resulting autoscaled $z_{i j}$ were used instead of the original $x_{i j}$ :

$$
z_{i j}=\frac{\left(x_{i j}-x_{j}\right)}{s_{j}} .
$$

As a result of this autoscaling, each variable has about the same range and it is avoided that some variables would be more important than others because of scale effects. In the present study, PCA was attempted by SPSS (version 10.0) by adopting Varimax procedure for rotation of factor matrix into one that was easier to interpret. Deciding the number of factors to retain for each data set is a critical issue. Retaining too few factors results in combining different sources, while retaining too many factors splits sources among factors in a physically unreasonable manner. The number of factors to be retained was decided on the basis of the breaks in the slopes of scree plots that are plots between eigen values and PCs as shown in Figure 1(a). PCs with eigen values greater than 1 were retained as they provided a reasonable physical interpretation of sources. The PCs were interpreted on the basis of their loadings. Factor loadings greater than 0.5 were considered statistically significant. The factor profiles were constructed on the basis of factor loadings. These are shown in Figure 1(b). Three factors were obtained. They explained approximately $80 \%$ of the total variance of data. Factor 1 was associated with $\mathrm{BaA}+\mathrm{Chr}$, Fla, BbF $+\mathrm{BkF}, \mathrm{BaP}$, Flu, and $\mathrm{Pyr}$ and accounted for $44 \%$ of the total variance.

This factor was attributed to industrial emissions (stationary source). $\mathrm{BbF}$ and $\mathrm{BkF}$ are indicators of diesel exhaust emissions mainly emitted from diesel generators that are frequently operated during power cuts in the various industrial units located in this area and partly also contributed by heavy duty diesel vehicles plying around the area. Fla, Pyr, BaP, and $\mathrm{BaA}+\mathrm{Chr}$ in this factor can be associated to emissions from natural gas combustion. $\mathrm{BaA}, \mathrm{Chr}$, and $\mathrm{BaP}$ are associated with combustion of natural gas $[16,27,52]$ and $\mathrm{BaA}$ has been considered as a tracer for this source [52]. The presence of Chr with BaA, Fla, and Pyr in natural gas combustion has also been reported by Daisey et al. [62]. Factor 2 explains $22 \%$ of the total variance and includes Acy, Ace, Flu, Phen, and Anth. This factor can be attributed to coal and wood combustion. Khalili et al. [49] identified that Ant, Phe, Fla, and Pyr were source fingerprints of wood combustion, while the third factor explaining $14 \%$ of the variance can be associated to emissions from gasoline vehicles showing higher loadings on BghiP and DbA + IP.

3.3. Health Risk Assessment. An essential prerequisite for determining the human health risk associated with PAH in the environment is accurately characterizing the toxicities of individual PAH. As the toxicities of individual PAH differ considerably, toxicity assessments of PAH are complex [63]. 
TABle 4: Proposed Toxic Equivalency Factors (TEFs) for individual PAHs and calculated TEF-adjusted concentrations of measured samples.

\begin{tabular}{lcc}
\hline PAH & TEF (data from [69]) & $\begin{array}{c}\text { TEF-adjusted concentrations in ng } \mathrm{m}^{-3} \\
\text { (Present Study) }^{-3}\end{array}$ \\
\hline Naphthalene (NaP) & 0.001 & 0.0009 \\
Acenaphthylene (Acy) & 0.001 & 0.0017 \\
Acenaphthene (Ace) & 0.001 & 0.0018 \\
Fluorene (Flu) & 0.001 & 0.0010 \\
Phenanthrene (Phen) & 0.001 & 0.0009 \\
Anthracene (Anth) & 0.01 & 0.0223 \\
Fluoranthene (Fla) & 0.001 & 0.0002 \\
Pyrene (Pyr) & 0.001 & 0.0031 \\
Benzo(a)anthracene (BaA) & 0.1 & 0.616 \\
Chrysene (Chr) & 0.01 & 0.079 \\
Benzo(b)fluoranthene & & 1.064 \\
Benzo(k)fluoranthene (BbF + BkF) & 0.1 & 0.984 \\
Benzo(k)fluoranthene (BkF) & 0.1 & 12.27 \\
Benzo(a)pyrene (BaP) & 1 & 1.479 \\
Indeno(123-cd)pyrene (IP) & 0.1 & 0.023 \\
Dibenz(ah)anthracene (DbA) & 1 & 11.13 \\
B(ghi)perylene (BghiP) & 0.01 & \\
\hline
\end{tabular}

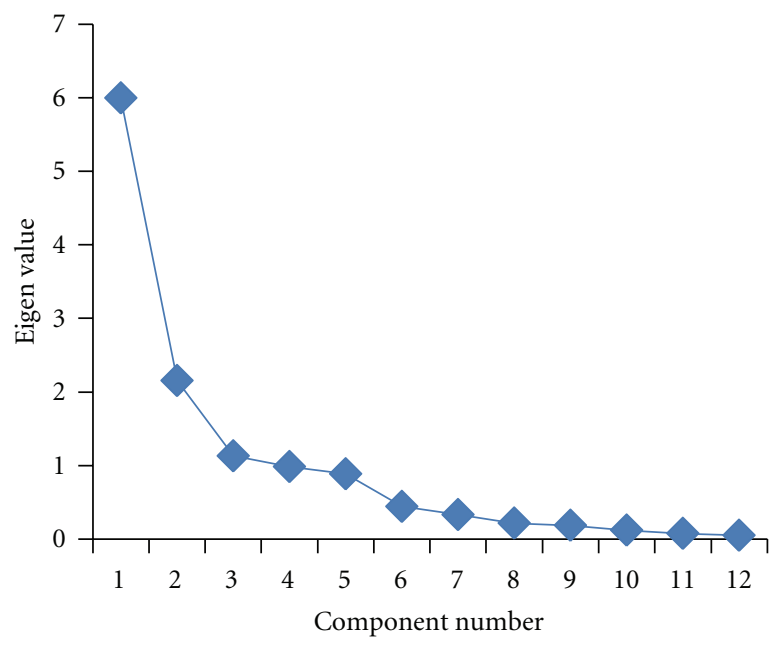

(a)

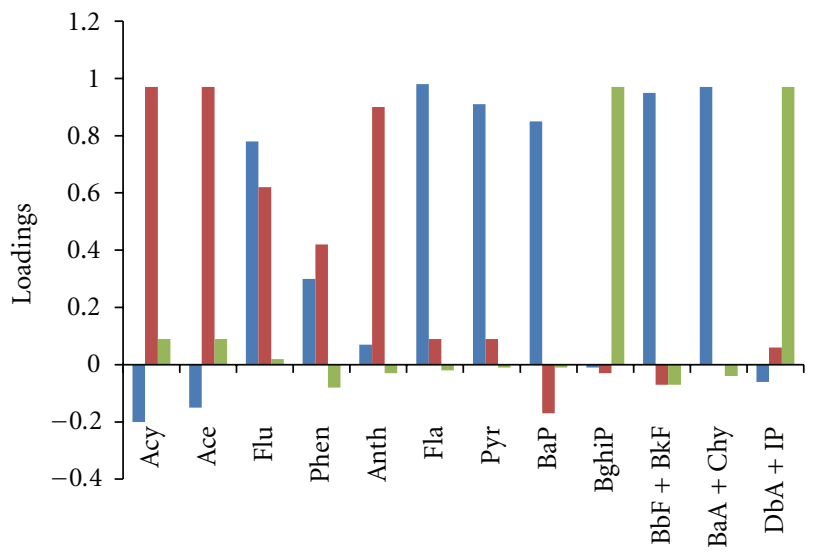

PAH

Factor 1

Factor 2

Factor 3

Figure 1: (a) Scree plot. (b) Factor profile.

One approach commonly referred as the Toxic equivalence Factor (TEF) calculates the inhalation risk for excess lung cancer over the risk posed by $\mathrm{BaP}$ for each of its copollutant carcinogenic PAH in the polluted ambient air [64]. TEFs are toxicity potency factors that are used by scientists and regulators globally as a consistent method to evaluate the toxicities of highly variable mixtures of PAH compounds. TEF was initially developed for estimation of the risk caused by complex mixtures, such as dioxins, and could help to characterize more precisely the carcinogenic properties of complex mixtures. The method relates individual compound toxic potency to a compound, often the most toxic compound in the mixture [65]. A few proposals for TEFs are available [66-70]; among these the list of TEFs completed by Nisbet and LaGoy [69] reflects well the actual knowledge of the toxic potency of each individual PAH compound [70]. In the $\mathrm{PAH}$ family, BaP the most toxic member, is assigned a TEF of one. According to this approach the health risk assessment of PAHs can be assessed based on its BaP equivalent concentration (BaPeq). BaPeq concentration for each PAH 
is calculated by multiplying its concentration with the corresponding TEF. The carcinogenic potency of total PAHs can be assessed by the sum of the BaPeq concentration of each PAHs. The TEFs-adjusted concentrations of each PAH along with their proposed TEFs are presented in Table 4. The total BaPeq concentration was found to be $27.6 \mathrm{ng} \mathrm{m}^{-3}$. The LMW compounds show only a negligible contribution towards carcinogenicity. The major contributor is $\mathrm{BaP}$ followed by BghiP. This underlines and confirms the importance of $\mathrm{BaP}$ and BghiP as a surrogate compound for $\mathrm{PAH}$ mixture in ambient air. The carcinogenic PAHs (BbF, BkF, BaP, BghiP, and IP) accounted for $97 \%$ of the total BaPeq concentrations which is similar to $97 \%$ and $93 \%$ in Ho Chi Minh city, Vietnam, and Osaka, Japan, respectively [58]. These results imply that particle bound PAHs with high molecular weight play an important role on total $\mathrm{BaP}$ eq concentration from health risk point of view. Other compounds like Acy, Ace, Anth, Pyr, BaA, and Chr which also dominate in the $\mathrm{PAH}$ mixture obviously play a minor role in the carcinogenicity of the PAH mixture in ambient air.

\section{Conclusion}

In this study, TSP samples were collected and quantified for $16 \mathrm{PAH}$ compounds. Mean total PAH concentration was found to be $72.7 \pm 4.7 \mathrm{ng} \mathrm{m}^{-3}$ that is lower than the permissible exposure limit $\left(0.2 \mathrm{mg} \mathrm{m}^{-3}\right)$ of PAH set by the Occupational Safety and Health Administration (OSHA). The high molecular weight PAHs, namely, BghiP, DbA, IP, and $\mathrm{BaP}$ were the most abundant. Average $\mathrm{BaP}$ concentration was $12.3 \mathrm{ng} \mathrm{m}^{-3}$. Concentrations of Total PAHs as well as the individual compounds were lower in summer than in winter. Diagnostic ratios and principal component analysis indicated that the influences of vehicular sources and stationary sources involving both diesel and natural gas combustion were the principal sources while emissions from coal-, coke-, and gasoline-driven vehicles had a minor contribution.

\section{Acknowledgment}

The author is grateful to the Director, Dayalbagh Educational Institute Agra, Head, Department of Chemistry and Department of Science and Technology, Project no. SR/S4/ AS:282/07, New Delhi, for financial assistance.

\section{References}

[1] E. Velasco, P. Siegmann, and H. C. Siegmann, "Exploratory study of particle-bound polycyclic aromatic hydrocarbons in different environments of Mexico City," Atmospheric Environment, vol. 38, no. 29, pp. 4957-4968, 2004.

[2] D. Golomb, E. Barry, G. Fisher, P. Varanusupakul, M. Koleda, and T. Rooney, "Atmospheric deposition of polycyclic aromatic hydrocarbons near New England coastal waters," Atmospheric Environment, vol. 35, no. 36, pp. 6245-6258, 2001.

[3] K. Ravindra, L. Bencs, E. Wauters et al., "Seasonal and site-specific variation in vapour and aerosol phase PAHs over Flanders (Belgium) and their relation with anthropogenic activities," Atmospheric Environment, vol. 40, no. 4, pp. 771-785, 2006.
[4] K. Ravindra, R. Sokhi, and R. Van Grieken, "Atmospheric polycyclic aromatic hydrocarbons: source attribution, emission factors and regulation," Atmospheric Environment, vol. 42, no. 13, pp. 2895-2921, 2008.

[5] X. Wang, H. Cheng, X. Xu, G. Zhuang, and C. Zhao, "A wintertime study of polycyclic aromatic hydrocarbons in PM2.5 and PM2.5-10 in Beijing: assessment of energy structure conversion," Journal of Hazardous Materials, vol. 157, no. 1, pp. 47-56, 2008.

[6] K. F. Chang, G. C. Fang, J. C. Chen, and Y. S. Wu, "Atmospheric polycyclic aromatic hydrocarbons (PAHs) in Asia: a review from 1999 to 2004," Environmental Pollution, vol. 142, no. 3, pp. 388-396, 2006.

[7] N. Rajput and A. Lakhani, "Measurements of polycyclic aromatic hydrocarbons in an urban atmosphere of Agra, India," Atmosfera, vol. 23, no. 2, pp. 165-183, 2010.

[8] S. O. Baek, R. A. Field, M. E. Goldstone, P. W. Kirk, J. N. Lester, and R. Perry, "A review of atmospheric polycyclic aromatic hydrocarbons: sources, fate and behavior," Water, Air, and Soil Pollution, vol. 60, no. 3-4, pp. 279-300, 1991.

[9] N. Ré-Poppi and M. Santiago-Silva, "Polycyclic aromatic hydrocarbons and other selected organic compounds in ambient air of Campo Grande City, Brazil," Atmospheric Environment, vol. 39, no. 16, pp. 2839-2850, 2005.

[10] S. S. Park, Y. J. Kim, and C. H. Kang, "Atmospheric polycyclic aromatic hydrocarbons in Seoul, Korea," Atmospheric Environment, vol. 36, no. 17, pp. 2917-2924, 2002.

[11] C. V. Raiyani, J. P. Jani, N. M. Desai, J. A. Shaha, and S. K. Kashyap, "Levels of polycyclic aromatic hydrocarbons in ambient environment of Ahmedabad," Indian Journal of Environmental Protection, vol. 13, pp. 206-216, 1993.

[12] G. G. Pandit, S. Sharma, A. M. Mohan Rao, and T. M. Krishnamoorthy, "Chromatographic methods for the estimation of polycyclic aromatic hydrocarbons in atmospheric particulates," in Proceeding of the 5th National Symposium on Environment, pp. 133-136, 1996.

[13] R. Vaishali, K. M. Phadke, R. Thakre, and M. Z. Hasan, "PAHs in respirable particulate matter in Nagpur city," Journal of the Indian Association for Environmental Management, vol. 24, pp. 11-16, 1997.

[14] G. Chattopadhyay, G. Samanta, S. Chatterjee, and D. Chakraborti, "Determination of particulate phase polycyclic aromatic hydrocarbons in ambient air of Calcutta for three years during winter," Environmental Technology, vol. 19, no. 9, pp. 873-882, 1998.

[15] P. Kulkarni, Chemical Mass Balance for source apportionment of particulate polycyclic aromatic hydrocarbons in Indian Cities, M.S. thesis, Centre for Environmental Science and Engineering, Indian Institute of Technology, Bombay, India, 1997.

[16] P. Kulkarni and C. Venkataraman, "Atmospheric polycyclic aromatic hydrocarbons in Mumbai, India," Atmospheric Environment, vol. 34, no. 17, pp. 2785-2790, 2000.

[17] H. Sharma, V. K. Jain, and Z. H. Khan, "Atmospheric polycyclic aromatic hydrocarbons (PAHs) in the urban air of Delhi during 2003," Environmental Monitoring and Assessment, vol. 147, no. 1-3, pp. 43-55, 2008.

[18] S. Saksena, Integrated exposure assessment of airborne pollutants in an urban community using biomass and kerosene cooking fuels, Ph.D. thesis, Centre for Environmental Science and Engineering, Indian Institute of Technology, Bombay, India, 1999.

[19] NAAQMS, National Ambient Air Quality Monitoring Series: NAAQMS/28/2006-2007. Urban Air Monitoring: A Case Study 
in Agra 2002-2006, Central Pollution Control Board, New Delhi, India, 2006.

[20] RTO. Road Traffic Office. Transport Nagar Agra, India. Personal Communication, 2008.

[21] N. Rajput and A. Lakhani, "Measurements of polycyclic aromatic hydrocarbons at an industrial site in India," Environmental Monitoring and Assessment, vol. 150, no. 1-4, pp. 273284, 2009.

[22] NHAI, National Highway Authority of India, Data from Shipping, Ministry of Road Transport and Highways, Delhi to Agra ( $\mathrm{km} 108$ to 199.63) at Madhuvan, India, 2007.

[23] N. Rajput, L. D. Khemani, and A. Lakhani, "Determination of polycyclic aromatic hydrocarbons in atmospheric particulate matter using gas chromatography," Pollution Research, vol. 26, no. 4, pp. 541-549, 2007.

[24] P. C. Vasconcellos, D. Zacarias, M. A. F. Pires, C. S. Pool, and L. R. F. Carvalho, "Measurements of polycyclic aromatic hydrocarbons in airborne particles from the metropolitan area of São Paulo City, Brazil," Atmospheric Environment, vol. 37, no. 21, pp. 3009-3018, 2003.

[25] N. Rajput and A. Lakhani, "PAHs and their carcinogenic potencies in diesel fuel and diesel generator exhaust," Human and Ecological Risk Assessment, vol. 15, no. 1, pp. 201-213, 2009.

[26] Parivesh, Polycyclic Aromatic Hydrocarbons in Air and Their Effects on Human Health, Central Pollution Control Board, Ministry of Environment and Forests, 2003.

[27] W. F. Rogge, L. M. Hildemann, M. A. Mazurek, G. R. Cass, and B. R. T. Simoneit, "Sources of fine organic aerosol. 2. Noncatalyst and catalyst-equipped automobiles and heavy-duty diesel trucks," Environmental Science and Technology, vol. 27, no. 4, pp. 636-651, 1993.

[28] A. D. Pereira Netto, I. F. Cunha, F. C. Muniz, and E. C. P. Rego, "Polycyclic aromatic hydrocarbons in street Dust of Niteroi City, RJ, Brazil," Bulletin of Environmental Contamination and Toxicology, vol. 72, no. 4, pp. 829-835, 2004.

[29] ATSDR (Agency for Toxic Substances and Disease Registry), Toxicological Profile for Polycyclic Aromatic Hydrocarbons (PAHs), US Department of Health and Human Services, Atlanta, Ga, USA, 1995.

[30] A. M. Mastral, M. S. Callén, J. M. López, R. Murillo, T. García, and M. V. Navarro, "Critical review on atmospheric PAH. Assessment of reported data in the Mediterranean basin," Fuel Processing Technology, vol. 80, no. 2, pp. 183-193, 2003.

[31] C. Bourotte, M. C. Forti, S. Taniguchi, M. C. Bícego, and P. A. Lotufo, "A wintertime study of PAHs in fine and coarse aerosols in São Paulo city, Brazil," Atmospheric Environment, vol. 39, no. 21, pp. 3799-3811, 2005.

[32] R. Mohanraj, G. Solaraj, and S. Dhanakumar, "PM 2.5 and $\mathrm{PAH}$ concentrations in urban atmosphere of Tiruchirappalli, India," Bulletin of Environmental Contamination and Toxicology, vol. 87, no. 3, pp. 330-335, 2011.

[33] A. Masih, R. Saini, R. Singhvi, and A. Taneja, "Concentrations, sources, and exposure profiles of polycyclic aromatic hydrocarbons (PAHs) in particulate matter (PM10) in the north central part of India," Environmental Monitoring and Assessment, vol. 163, no. 1-4, pp. 421-431, 2010.

[34] H. Sharma, V. K. Jain, and Z. H. Khan, "Characterization and source identification of polycyclic aromatic hydrocarbons (PAHs) in the urban environment of Delhi," Chemosphere, vol. 66, no. 2, pp. 302-310, 2007.

[35] M. Tsapakis and E. G. Stephanou, "Occurrence of gaseous and particulate polycyclic aromatic hydrocarbons in the urban atmosphere: study of sources and ambient temperature effect on the gas/particle concentration and distribution," Environmental Pollution, vol. 133, no. 1, pp. 147-156, 2005.
[36] E. G. Sanderson, A. Raqbi, A. Vyskocil, and J. P. Farant, "Comparison of particulate polycyclic aromatic hydrocarbon profiles in different regions of Canada," Atmospheric Environment, vol. 38, no. 21, pp. 3417-3429, 2004.

[37] A. Eiguren-Fernandez, A. H. Miguel, J. R. Froines, S. Thurairatnam, and E. L. Avol, "Seasonal and spatial variation of polycyclic aromatic hydrocarbons in vapor-phase and PM2.5 in Southern California urban and rural communities," Aerosol Science and Technology, vol. 38, no. 5, pp. 447-455, 2004.

[38] J. Li, G. Zhang, X. D. Li, S. H. Qi, G. Q. Liu, and X. Z. Peng, "Source seasonality of polycyclic aromatic hydrocarbons (PAHs) in a subtropical city, Guangzhou, South China," Science of the Total Environment, vol. 355, no. 1-3, pp. 145-155, 2006.

[39] J. H. Tan, X. H. Bi, J. C. Duan, K. A. Rahn, G. Y. Sheng, and J. M. Fu, "Seasonal variation of particulate polycyclic aromatic hydrocarbons associated with PM10 in Guangzhou, China," Atmospheric Research, vol. 80, no. 4, pp. 250-262, 2006.

[40] G. Dörr, M. Hippelein, H. Kaupp, and O. Hutzinger, "Baseline contamination assessment for a new resource recovery facility in Germany: part VI: levels and profiles of polycyclic aromatic hydrocarbons (PAH) in ambient air," Chemosphere, vol. 33, no. 8, pp. 1569-1578, 1996.

[41] D. W. M. Sin, Y. C. Wong, Y. Y. Choi, C. H. Lam, and P. K. K. Louie, "Distribution of polycyclic aromatic hydrocarbons in the atmosphere of Hong Kong," Journal of Environmental Monitoring, vol. 5, no. 6, pp. 989-996, 2003.

[42] D. Ludykar, R. Westerholm, and J. Almén, "Cold start emissions at $+22,-7$ and $-20 \circ \mathrm{C}$ ambient temperatures from a three-way catalyst (TWC) car: regulated and unregulated exhaust components," Science of the Total Environment, vol. 235, no. 1-3, pp. 65-69, 1999.

[43] R. M. Harrison, D. I. T. Smith, and L. Luhana, "Source apportionment of atmospheric polycyclic aromatic hydrocarbons collected from an urban location in Birmingham, U.K," Environmental Science and Technology, vol. 30, no. 3, pp. 825832, 1996.

[44] A. M. Caricchia, S. Chiavarini, and M. Pezza, "Polycyclic aromatic hydrocarbons in the urban atmospheric particulate matter in the city of Naples (Italy)," Atmospheric Environment, vol. 33, no. 23, pp. 3731-3738, 1999.

[45] T. Ohura, T. Amagai, T. Sugiyama, M. Fusaya, and H. Matsushita, "Characteristics of particle matter and associated polycyclic aromatic hydrocarbons in indoor and outdoor air in two cities in Shizuoka, Japan," Atmospheric Environment, vol. 38, no. 14, pp. 2045-2054, 2004.

[46] H. Guo, S. C. Lee, K. F. Ho, X. M. Wang, and S. C. Zou, "Particle-associated polycyclic aromatic hydrocarbons in urban air of Hong Kong," Atmospheric Environment, vol. 37, no. 38, pp. 5307-5317, 2003.

[47] A. H. Miguel, T. W. Kirchstetter, R. A. Harley, and S. V. Hering, "On-road emissions of particulate polycyclic aromatic hydrocarbons and black carbon from gasoline and diesel vehicles," Environmental Science and Technology, vol. 32, no. 4, pp. 450-455, 1998.

[48] P. Masclet, G. Mouvier, and K. Nikolaou, "Relative decay index and sources of polycyclic aromatic hydrocarbons," Atmospheric Environment, vol. 20, no. 3, pp. 439-446, 1986.

[49] N. R. Khalili, P. A. Scheff, and T. M. Holsen, "PAH source fingerprints for coke ovens, diesel and gasoline engines, highway tunnels, and wood combustion emissions," Atmospheric Environment, vol. 29, no. 4, pp. 533-542, 1995.

[50] C. K. Li and R. M. Kamens, "The use of polycyclic aromatic hydrocarbons as source signatures in receptor modeling," Atmospheric Environment, vol. 27, no. 4, pp. 523-532, 1993. 
[51] M. A. Sicre, J. C. Marty, A. Saliot, X. Aparicio, J. Grimalt, and J. Albaiges, "Aliphatic and aromatic hydrocarbons in different sized aerosols over the Mediterranean Sea: occurrence and origin," Atmospheric Environment, vol. 21, no. 10, pp. 22472259, 1987.

[52] M. F. Simcik, H. Zhang, S. J. Eisenreich, and T. P. Franz, "Urban contamination of the Chicago/Coastal Lake Michigan atmosphere by PCBs and PAHs during AEOLOS," Environmental Science and Technology, vol. 31, no. 7, pp. 2141-2147, 1997.

[53] N. Tang, T. Hattori, R. Taga et al., "Polycyclic aromatic hydrocarbons and nitropolycyclic aromatic hydrocarbons in urban air particulates and their relationship to emission sources in the Pan-Japan Sea countries," Atmospheric Environment, vol. 39, no. 32, pp. 5817-5826, 2005.

[54] G. Grimmer, J. Jacob, and K. W. Naujack, "Profile of the polycyclic aromatic compounds from crude oils. Part 3. Inventory by GCGC/MS.-PAH in environmental materials," Fresenius Zeitschrift fur Analytische Chemie Labor und Betriebsverfahren, vol. 314, no. 1, pp. 29-36, 1983.

[55] I. G. Kavouras, P. Koutrakis, M. Tsapakis et al., "Source apportionment of urban particulate aliphatic and polynuclear aromatic hydrocarbons (PAHs) using multivariate methods," Environmental Science and Technology, vol. 35, no. 11, pp. 2288-2294, 2001.

[56] E. Galarneau, "Source specificity and atmospheric processing of airborne PAHs: implications for source apportionment," Atmospheric Environment, vol. 42, no. 35, pp. 8139-8149, 2008.

[57] J. Mantis, A. Chaloulakou, and C. Samara, "PM10-bound polycyclic aromatic hydrocarbons (PAHs) in the Greater Area of Athens, Greece," Chemosphere, vol. 59, no. 5, pp. 593-604, 2005.

[58] T. T. Hien, P. P. Nam, S. Yasuhiro, K. Takayuki, T. Norimichi, and B. Hiroshi, "Comparison of particle-phase polycyclic aromatic hydrocarbons and their variability causes in the ambient air in Ho Chi Minh City, Vietnam and in Osaka, Japan, during 2005-2006," Science of the Total Environment, vol. 382, no. 1, pp. 70-81, 2007.

[59] M. D. R. Sienra, N. G. Rosazza, and M. Préndez, "Polycyclic aromatic hydrocarbons and their molecular diagnostic ratios in urban atmospheric respirable particulate matter," Atmospheric Research, vol. 75, no. 4, pp. 267-281, 2005.

[60] F. Tian, J. Chen, X. Qiao et al., "Sources and seasonal variation of atmospheric polycyclic aromatic hydrocarbons in Dalian, China: factor analysis with non-negative constraints combined with local source fingerprints," Atmospheric Environment, vol. 43, no. 17, pp. 2747-2753, 2009.

[61] G. Wang, L. Huang, Xin Zhao, H. Niu, and Z. Dai, "Aliphatic and polycyclic aromatic hydrocarbons of atmospheric aerosols in five locations of Nanjing urban area, China," Atmospheric Research, vol. 81, no. 1, pp. 54-66, 2006.

[62] J. M. Daisey, J. L. Cheney, and P. J. Lioy, "Profiles of organic particulate emissions from air pollution sources: status and needs for receptor source apportionment modeling," Journal of the Air Pollution Control Association, vol. 36, no. 1, pp. 1733, 1986.

[63] N. T. Kim Oanh, L. H. Nghiem, and Y. L. Phyu, "Emission of polycyclic aromatic hydrocarbons, toxicity, and mutagenicity from domestic cooking using sawdust briquettes, wood, and kerosene," Environmental Science and Technology, vol. 36, no. 5, pp. 833-839, 2002.

[64] A. Papageorgopoulou, E. Manoli, E. Touloumi, and C. Samara, "Polycyclic aromatic hydrocarbons in the ambient air of Greek towns in relation to other atmospheric pollutants," Chemosphere, vol. 39, no. 13, pp. 2183-2199, 1999.

[65] Z. Wang, J. Chen, P. Yang, X. Qiao, and F. Tian, "Polycyclic aromatic hydrocarbons in Dalian soils: distribution and toxicity assessment," Journal of Environmental Monitoring, vol. 9, no. 2, pp. 199-204, 2007.

[66] M. Chu and C. Chen, "Evaluation and estimation of potential carcinogenic risks of polynuclear aromatic hydrocarbons," in Proceedings of the Symposium on Polycyclic Aromatic Hydrocarbons in the Workplace, Pacific Rim Risk Conference, Honolulu, Hawaii, USA, December 1984.

[67] D. Krewski, T. Thorslund, and J. Withey, "Carcinogenic risk assessment of complex mixtures," Toxicology and Industrial Health, vol. 5, no. 5, pp. 851-867, 1989.

[68] T. Thorslund and D. Farrer, Development of Relative Potency Estimates for PAHs and Hydrocarbon Combustion Product Fractions Compared to Benzo(a)Pyrene and Their Use in Carcinogenic Risk Assessments, United States Environmental Protection Agency, 1991.

[69] I. C. T. Nisbet and P. K. LaGoy, "Toxic equivalency factors (TEFs) for polycyclic aromatic hydrocarbons (PAHs)," Regulatory Toxicology and Pharmacology, vol. 16, no. 3, pp. 290-300, 1992.

[70] T. Petry, P. Schmid, and C. Schlatter, "The use of toxic equivalency factors in assessing occupational and environmental health risk associated with exposure to airborne mixtures of polycyclic aromatic hydrocarbons (PAHs)," Chemosphere, vol. 32, no. 4, pp. 639-648, 1996. 

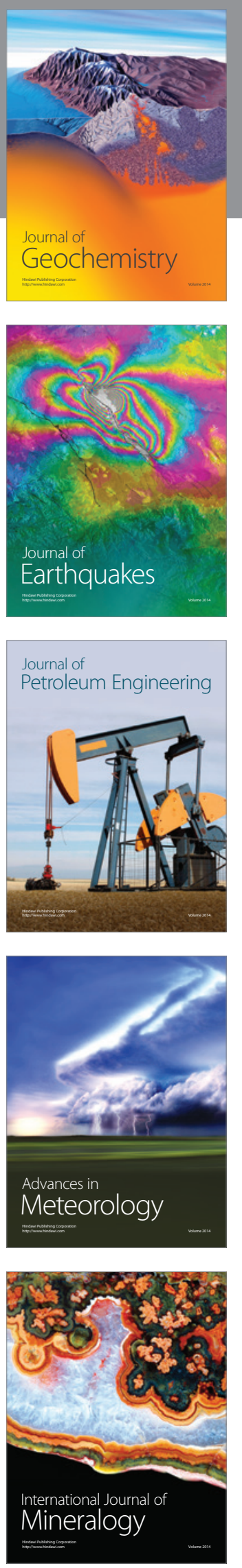
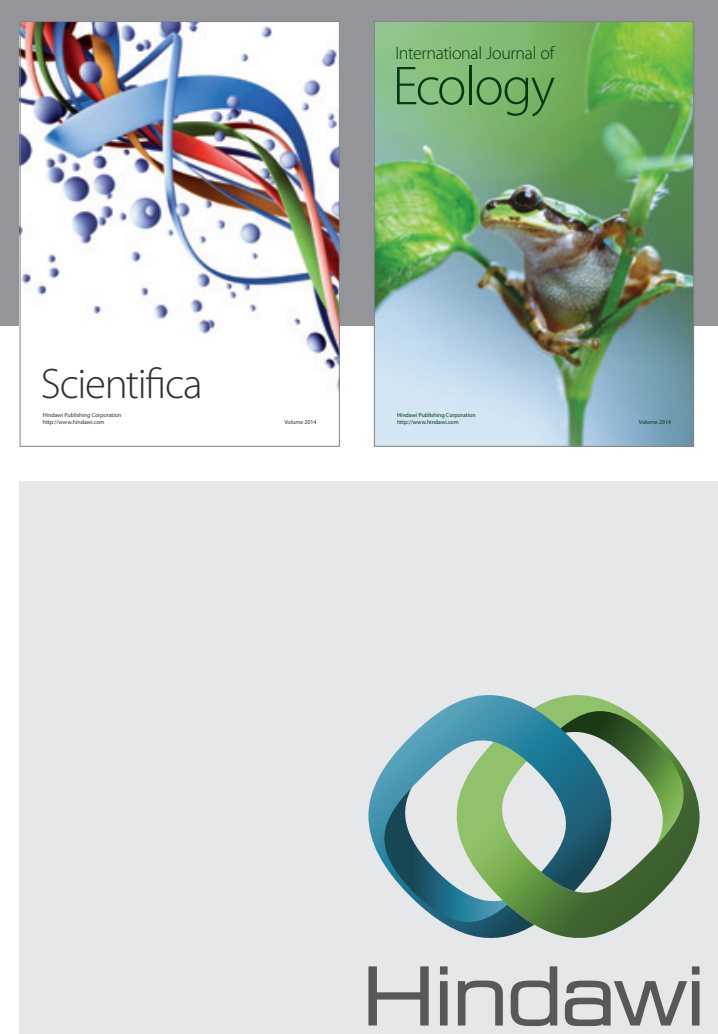

Submit your manuscripts at http://www.hindawi.com
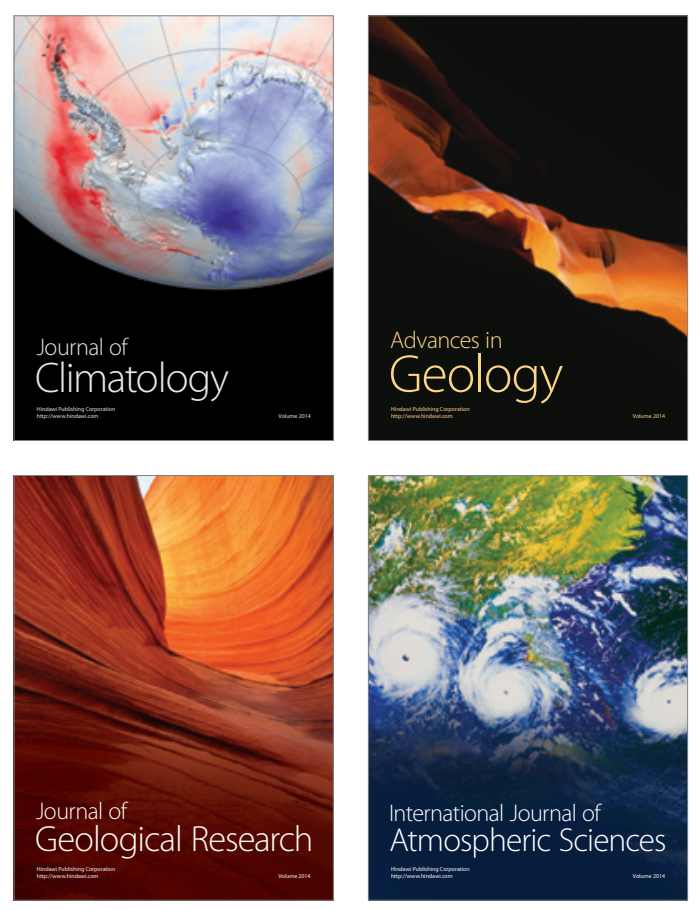
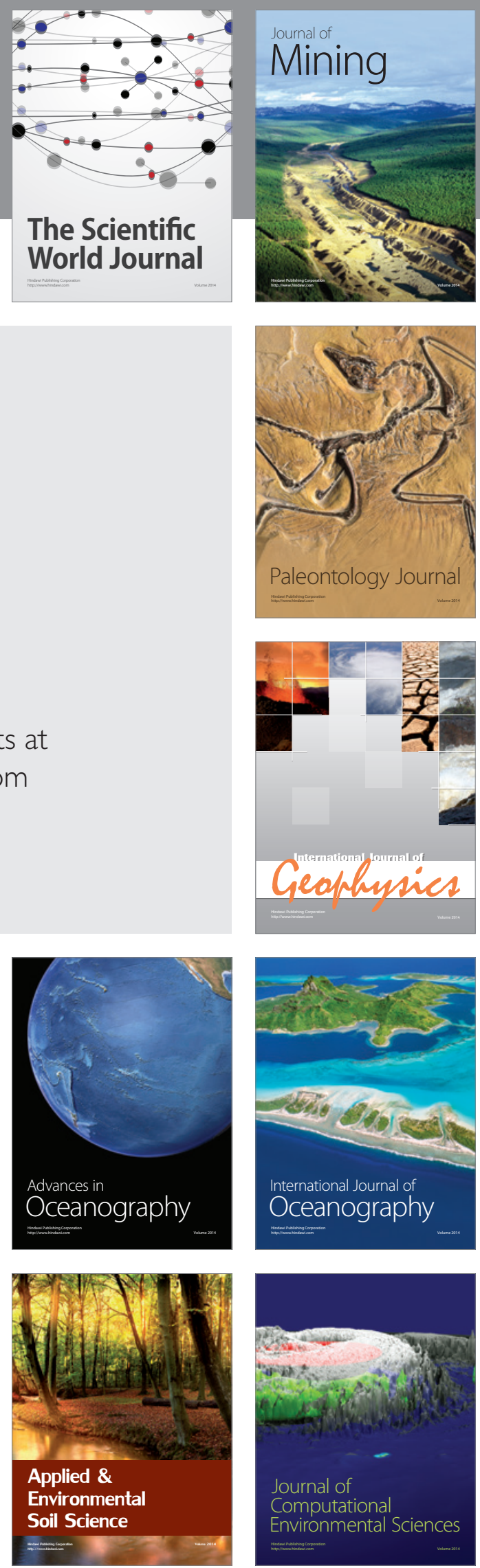